\title{
Potential Partnership of Community-Based Management in Supporting The Utilization of Sustainable Resources in Indonesian Coastal Tourism1
}

\author{
Saiqa Ilham Akbar", Anisa Nurpita", Elton Buyung Satrianto* \\ * Universitas Gadjah Mada \\ Vocational College, Department of Economics of Business \\ Prof. Notonagoro Street, Bulaksumur, Yogyakarta 55281, Indonesia \\ E-mail: saiqailham88@ugm.ac.id
}

\begin{abstract}
Abstrak
Penerapan community-based management (CBM) dalam mengelola pariwisata pantai di Indonesia masih terbatas pada memberikan manfaat jangka pendek, terutama bagi masyarakat lokal dan tidak menjamin keberlanjutan sumber daya secara luas. Di sisi lain, sebagian besar kemitraan CBM di Indonesia masih terbatas pada hubungan antara pemerintah daerah dan masyarakat setempat dan tidak ada skema kemitraan yang jelas dalam melibatkan peran pihak ketiga dan sektor swasta yang dapat meningkatkan manfaat penerapan CBM. Studi ini bertujuan untuk meninjau dan mengevaluasi kebijakan dan implementasi CBM di pariwisata pantai di Indonesia, mengidentifikasi efektivitas implementasi CBM, dan menyarankan skema kemitraan CBM yang optimal dalam pariwisata pantai di Indonesia. Data yang digunakan adalah data primer melalui kuesioner, wawancara, dan diskusi kelompok terarah (FGD). Responden dalam penelitian ini meliputi anggota asosiasi hotel dan restoran, manajer CBM, pemerintah daerah, dan pengusaha di kawasan wisata pantai. Penelitian ini menggunakan indeks daya tarik investasi untuk mengukur efektivitas CBM di setiap tujuan wisata pantai. Temuan menunjukkan bahwa penerapan CBM dalam pariwisata pantai Indonesia sebagian besar disukai masyarakat lokal tetapi sedikit menarik perhatian dari investasi yang lebih besar terutama karena ada kurangnya peraturan terkait lahan yang jelas yang ditetapkan oleh pemerintah daerah di wilayah pesisir.
\end{abstract}

Kata kunci: CBM, wisata pesisir, komunitas lokal, investasi

\begin{abstract}
The application of community-based management (CBM) in managing coastal tourism in Indonesia is still limited to providing short-term benefits, especially for local communities and does not guarantee the sustainability of resources at large. On the other hand, most CBM partnership in Indonesia are still limited to the relationship between the local government and local communities and there is no clear partnership scheme in involving the role of third parties and private sectors that can increase the benefits of implementing CBM. This study aims to review and evaluate CBM policies and implementation in the coastal tourism in Indonesia, identifies the effectiveness of CBM implementations, and suggest an optimal CBM partnership scheme in the coastal tourism in Indonesia. The data used are primary data through questionnaires, interviews, and focus group discussion (FGD). Respondents in this study include members of hotel and restaurant association, CBM managers, local government, and businessmen in the coastal tourism area. This study uses investment attractiveness index to measure the effectiveness of CBM in each coastal tourism destination. The findings shows that the implementation of CBM in Indonesian coastal tourism mostly favored the local communities but draws little attention from bigger investment mainly because there is a lack of clear land regulation set by local government in coastal area.

Keywords: CBM, coastal tourism, local communities, investment
\end{abstract}

\section{Introduction}

As an archipelago with abundant marine resources, the management of marine resources in
Indonesia is still not optimized compared to the potential stored there [1]. The potential of marine resources owned in Indonesia is very diverse such as the biological resources, mineral and energy resources,

Funded by Dosen Muda Research Incentive in Gadjah Mada University

61 | Jurnal Akuntansi, Ekonomi dan Manajemen Bisnis | Vol. 8 No.1, July 2020, 61-66 | E-ISSN: 2548-9836 
maritime industry and services, sea transportation and environmental services, as well as the cultural potential involved in it. Meanwhile, in the management of marine resources, there are issues that need to be addressed such as community poverty, spatial use conflicts, environmental degradation, global climate change, and unsustainable resources management. This has led to a more decentralized coastal resource management policy direction at the top micro level through the management of marine resources that are managed and can be strengthened by the community in accordance with the 2016-2019 Indonesian Ocean Policy Action Plan.

Research conducted by Rahayu, et.al. shows that the development of CBM in Indonesia is limited to local governments as the only catalysts [2]. The research also shows that there are still a number of factors that can hamper CBM development, namely infrastructure that is not yet supportive, community participation in developing CBM is still low, and partnerships that have not been established optimally.

There are several coastal resource management practices through the CBM approach that exist in Indonesia, both those that have developed well and those that are still pioneering them. One example of management with the CBM approach is the management of coastal tourism in Mancingan XI, Parangtritis Village, Kretek, Bantul [3]. Other examples are Siliran Beach, Trisik Beach, Bugel Beach, Congot Beach, and Glagah Beach in Kulonprogo Regency [2]. Although not many studies have tried to evaluate the performance of CBM in Indonesia, previous study stated that in the application of CBM that is able to attract high involvement from the community, some cases show performance that meets the criteria for success with a note of the use of aid funds from external parties in this case is an independent PNPM fund from the government [4]. Research in the Langkai Islands, South Sulawesi also stated that community involvement in CBM was more inclined to short-term economic attractiveness which in the future could raise concerns from the sustainability of resource management through CBM [5].

CBM is not a perfect concept that promises success without adjusting the specific characteristics that exist in each location of its implementation. Research related to the implementation of CBM in Malawi and Botswana shows that the successful implementation of CBM in the two countries requires close multi-stakeholder collaboration between the government, international NGO institutions, and domestic NGO institutions supported by strong political will from local officials [6].

There are three major goals of developing coastal resources for tourism in the Sustainable Development Goals (SDGs), namely promoting sustainable, inclusive and sustainable economic growth, full and productive employment and decent work for all, ensuring sustainable consumption and production, and preserving and use marine and marine resources in a sustainable manner for development.

Based on the description that has been submitted, there are two main problems that form the basis of the need for this research. First is the application of CBM is still limited to providing short-term benefits, especially for local communities and does not guarantee the sustainability of resources at large. Second, most CBM applications are still limited to the relationship between the government and local communities and there is no clear partnership pattern in involving the role of third parties that can increase the benefits of implementing CBM to be more optimal.

Research will be conducted on the management of CBM in Indonesia given the number of CBM applications in the management of coastal resources in Indonesia and the direction of local government policies that support management with the CBM. This study seeks to measure the impact of implementing CBM and compare these impacts with the major goals of developing coastal resources based on the direction of the SDGs and to examine whether the role of the private sector as a third party can help CBM in achieving these larger goals. The results to be achieved from this research are the creation of an evaluation of the implementation of CBM in Indonesia and the direction of recommendations for the implementation of CBM going forward that has a greater and wider impact for all stakeholders.

\section{Community-based Management in Coastal Tourism}

$\mathrm{CBM}$ or in the field of tourism is often referred to as community-based tourism (CBT) is a concept of community-based management with a focus on empowering local communities. Tourism management in Indonesia broadly involves three main actors namely government, community and private sector [7]. Community empowerment through CBM becomes an important issue in tourism development in Indonesia, especially as an alternative to conventional tourism which is widely criticized for ignoring the rights and marginalizing local people from tourism activities in a destination.

CBM is also popular in other countries as a marine resource management solution where the government has limited management interventions. One country that is quite intensive in developing CBM in managing its resources is the Philippines which does have characteristics that are in accordance with the CBM concept. In a study conducted by [8], 16 CBMs that manage coastal resources obtained information that the implementation of the CBM was considered effective based on the eight indicators they developed. Still in Philippines, recent research also shows that CBM has a positive impact on equity and the sustainability of small-scale coastal resources [9].

Community-based resource management that 
promotes the empowerment of local communities when viewed from a broader perspective may not be in line with broader social objectives such as management efficiency and sustainability [10]. For example, in the management of community-based tourism, the factor of hygiene standards for food sold may be very important for visitors but is not a top priority for community-based tourism managers. The experience of existing community-based management shows that the role of intermediaries is important for communities to be able to articulate their needs and prioritize larger goals. These intermediaries can be in the form of government, NGOs or the private sector. Community-based managers need to be part of a larger goal so that they are not restricted to the level of management that is able to be managed at the community level without guidance from external parties.

CBM is an important concept in community empowerment so it is indeed needed especially in areas where government intervention capacity is still lacking However, when viewed from the ability to deliver services (service delivery) that is considered still lacking. The question that then arises is the extent to which management can be carried out at the community level and the extent to which assistance from external parties such as the private sector can and needs to be involved. To answer this question, it is necessary to first identify the broad objectives desired by broader stakeholders for the management of coastal resources and the extent to which service delivery is capable of being produced through the current community-based resource management.

\section{Methodology}

This research is a descriptive study that attempts to explain the opportunities for developing existing CBM by optimizing the role of partnerships between CBM managers and external parties. In addition, this research is also inductive by taking an approach based on phenomena that occur in the community and is expected to be generalized in broader practice.

The data used in this study are primary data. Primary data that are calculated are cross section data which means that this data is taken in the field within a certain time. This primary data was collected using a questionnaire, in-depth interview, and FGD (Forum Group Discussion). Respondents in this data collection are hotel and restaurant associations, CBM managers, business operators, and local governments.

The first step conducted ate reviewing and evaluating the existing CBM policy and application is needed as a basic point in developing CBM management going forward. Review and evaluation of CBM implementation policy is focused on aspects of CBM implementation developed from the three major objectives of developing coastal resources for tourism in the Sustainable Development Goals (SDGs) with a focus on stakeholders consisting of government, business actors, surrounding communities, and general public at large.

Secondly, another analytical tool used is the investment attractiveness index. The hierarchical structure of the industrial investment climate is made up of three levels, each of which influences the other levels in stages from bottom to top. The indicator used in this study is a development of the Indicators used by IFC, the World Bank in measuring the competitiveness of 152 countries in the world. Where in this study the Indicator is a hierarchy of levels, consisting of nine (defined) indicators and influencing the above levels (goal: industrial investment climate). Then the indicators are weighted. There are nine indicators to be measured, namely licensing, taxation, labor regulations, infrastructure (roads), public infrastructure (electricity, telephone, water and gas), security conditions, land acquisition for investment, access to corporate finance, and business environment conditions.

The result of investment attractiveness index will be tested using one-way Anova to test the difference between sample location of coastal tourism. According to [11], the mean difference test is a theory in statistics that is used to test whether a particular value (given as a comparison) differs significantly or not with the average of a sample. The mean difference test is only possible if the data used is quantitative, meaning that the data processed is only in the form of numbers.

Regression analysis is one of the data analysis techniques in statistics that is often used to study the relationship between several variables and predicting a variable [12]. Regression analysis will be used to predict variable in $\mathrm{CBM}$ partnership that contributing to the success of CBM implementation.

\section{Results}

Review and evaluation of CBM implementations. The results of the review and evaluation of policies and implementation of CBM in DIY are presented in the following table.

TABLE I

PERFORMANCE OF CBM IMPLEMENTATIONS

\begin{tabular}{|c|c|c|}
\hline No & Performance Aspects & Score \\
\hline 1 & Overall CBM implementations & $92.16 \%$ \\
\hline 2 & Local government support & $84.31 \%$ \\
\hline 3 & Positif impact for local communities & $100.00 \%$ \\
\hline 4. & Positif impact for general communities & $92.16 \%$ \\
\hline 5. & Positif impact for local businessmen & $92.16 \%$ \\
\hline 6. & Positif impact for economic development & $92.16 \%$ \\
\hline 7. & $\begin{array}{c}\text { Positif impact for natural resources } \\
\text { sustainability }\end{array}$ & $80.39 \%$ \\
\hline 8. & $\begin{array}{c}\text { Positif impact for improving tourism } \\
\text { attractiveness }\end{array}$ & $92.16 \%$ \\
\hline
\end{tabular}


$$
9 .
$$

All aspects of CBM implementation in coastal tourism showed very satisfying performance with more than $80 \%$ of respondents stated that CBM performance was good. The aspect that has the highest performance is the positive impact of the implementation of CBM for local communities around coastal tourism with all respondents saying the performance is good. In addition, there are six other aspects that are considered to have a very satisfying performance with a score above $90 \%$, namely the overall performance of CBM, the positive impact of CBM tourism management for the general public, the positive impact of CBM tourism management for business actors, CBM tourism management in encouraging growth economy in the area, CBM tourism management in increasing the attractiveness of coastal tourism, and CBM tourism management in increasing employment for the community. Three other aspects also have a good performance with a score above $80 \%$, namely aspects of local government policy support in supporting the implementation of tourism in CBM, CBM tourism management in encouraging the preservation of the existing coastal resource environment, and the commitment of regional heads in developing coastal tourism in CBM.

The overall effectiveness of CBM by stakeholders in coastal tourism is also measured using an investment attractiveness index consisting of nine factors. The results of measuring the effectiveness of $\mathrm{CBM}$ in coastal tourism are shown in the following table.

TABLE 2

INVESTMENT ATRRACTIVENESS INDEX

\begin{tabular}{|c|c|c|}
\hline No & Investment Attractiveness Factor & Score \\
\hline 1 & Licensing services & 4.22 \\
\hline 2 & Tax services & 4.22 \\
\hline 3 & Labor regulations & 3.67 \\
\hline 4. & Transportation facilities & 3.00 \\
\hline 5. & Public infrastructure & 3.00 \\
\hline 6. & Safety & 3.00 \\
\hline 7. & Land rules & 3.00 \\
\hline 8. & Financing & 3.89 \\
\hline 9. & Business Competition & 3.78 \\
\hline
\end{tabular}

With a measurement scale of 1 to 5 , there are four factors that get a neutral score which means the performance of the four factors is not considered bad but is also not considered good. The four factors include transportation facilities, public infrastructure, security, and land rules. In addition to these four factors, the other five factors are considered to have good performance with a score above 3.5 , namely licensing services, tax services, labor regulations, financing and business competition.

By using one-way Anova, overall, there were also no differences in performance based on the three districts that were used as the sampling locations. In other words, CBM performance based on the investment attractiveness index is uniform and consistent between coastal tourism sites. Anova test results are shown in the following table.

TABLE 3

ONE-WAY ANOVA RESULTS

\begin{tabular}{|c|c|c|c|}
\hline No & Aspects & F & Sig. \\
\hline 1 & licensing & 0.858 & 0.434 \\
\hline 2 & tax & 3.145 & 0.057 \\
\hline 3 & labor & 2.702 & 0.083 \\
\hline 4. & transport & 0.11 & 0.896 \\
\hline 5. & infrastructure & 0.293 & 0.748 \\
\hline 6. & safety & 1.379 & 0.267 \\
\hline 7. & land & 0.684 & 0.512 \\
\hline 8. & financing & 0.611 & 0.549 \\
\hline 9. & competition & 4.706 & 0.016 \\
\hline
\end{tabular}

With 0.05 significance level, only competition has different performance in according to the location of CBM implementations. Then, looking at each of these factors, only business competition factors that show significant differences between different coastal tourism sites. This can be understood because the level of crowd of each coastal tourist location is different and the difference in the crowd of visitors affects the number of entrepreneurs operating.

Based on information obtained from in-depth interviews and FGDs with stakeholders, there are several forms of partnerships that can be carried out by CBM managers with the private sector in supporting community-based tourism management. Some of the partnership patterns that can be carried out are company social responsibility (CSR), sponsorship, technology training / sharing, marketing cooperation, and investment cooperation. The partnership schemes identified were then measured in terms of their effect on the success of coastal tourism management with CBM. The analysis was performed using linear regression with the stepwise method to get the best model that is considered capable of explaining the success of coastal tourism management using CBM.

TABLE 4

REGRESSION ANALYSIS RESULTS

\begin{tabular}{|l|l|l|l|l|}
\hline \multicolumn{2}{|l|}{ Model } & $\begin{array}{l}\text { Unstandardized } \\
\text { Coefficients (B) }\end{array}$ & Sig. & $\begin{array}{l}\text { Adj. R } \\
\text { Square }\end{array}$ \\
\hline 1 & (Constant) & 2.643 & 0 & .214 \\
\hline
\end{tabular}




\begin{tabular}{|l|l|c|c|c|}
\hline & investation & 0.258 & 0.003 & \\
\hline 2 & (Constant) & 3.544 & 0 & \\
\hline & investation & 0.274 & 0 & \multirow{2}{*}{.623} \\
\hline & csr & -0.258 & 0.001 & \\
\hline
\end{tabular}

The results of the regression analysis using the stepwise method produce two models. The first model only includes investment cooperation factors as variables that explain the success of CBM in coastal tourism. On the other hand, in the second model, besides investment cooperation factors, CSR is also considered as a variable explaining the success of CBM in coastal tourism in Indonesia. The second model was chosen because it has a higher $\mathrm{R}$ squared value than the first model. In the second model, investment cooperation is considered to be able to increase the success of coastal tourism management using CBM while CSR is considered to have the opposite effect.

\section{Conclussions}

Based on the results of the analysis that has been done, the application of CBM in coastal tourism in Indonesia is considered to have been able to have a positive impact on stakeholders consisting of local communities, the general public, local entrepreneurs, regional economic development, and the sustainability of maritime resources. However, in line with the results of other studies, the positive impact of the implementation of CBM was felt the greatest on local communities. In addition, although a positive impact is also felt on the sustainability of maritime resources, the effect is not as high as other stakeholders who are directly affected by the management of coastal tourism on a CBM basis.

In terms of investment attractiveness, five of the nine factors show satisfactory results while the other four are considered not to show satisfactory performance. However, overall, CBM coastal tourism management performance is considered to be able to increase the attractiveness of coastal tourism investment in Indonesia. These results are also not too different between coastal tourism sites which are the object of research indicated by the results of the Anova one-way analysis. This is reasonable considering that the management of CBM that is still simple is generic in various regions.

The results of the regression analysis aimed at determining the optimal partnership pattern for the success of CBM in coastal tourism are carried out on forms of partnership such as CSR, sponsorship, technology sharing, marketing cooperation, and investment cooperation. Investment cooperation and CSR are considered to contribute to the success of CBM in coastal tourism in different ways. Based on the results of interviews and $\mathrm{FG}$, investment cooperation encourages the management of $\mathrm{CBM}$ in more advanced coastal tourism which because it encourages the emergence of new facilities at tourist sites thereby increasing the competitiveness of these tours. While CSR is actually considered to contribute negatively even though it is considered to have the same impact. The explanation obtained is that CSR grant received often does not have a direct impact on tourism performance and there is rarely a follow-up to the development of CSR grant provided.

The final conclusion, people who participate directly in the management of coastal tourism in the form of CBM tend to feel satisfied with the existing CBM management. They get the benefits as expected in the short term. However, awareness of the sustainability of coastal resources has not yet been raised in the community. CBM managers still do not consider the private sector as a collaborative partner in the development of coastal tourism and still rely on the role of local government and regionally owned companies. On the other hand, the private sector is also still reluctant to invest in coastal areas due to lack of clarity regarding land-related regulations, especially in Yogyakarta Province because of its status as imperial-owned land and disaster-prone areas.

\section{Acknowledgment}

The authors gratefully acknowledge the contributions of research directorate of Gadjah Mada University for the funding on this study, the support from local government in Kulonprogo, Bantul and Gunungkidul Regency in Yogyakarta, and contribution from CBM managers in coastal tourism in Yogyakarta.

\section{References}

A. Lasabuda, R. "Pembangunan Wilayah Pesisir dan Lautan dalam Perspektif Negara Kepulauan Indonesia". Jurnal Ilmiah Platax, 1 (2), pp.92-101, 2013.

B. Rahayu, S., Dewi, U. and Fitriana, K. "Pengembangan Pariwisata Berbasis Masyarakat (Community-based Tourism) di Kabupaten Kulonprogo Daerah Istimewa Yogyakarta”. Adinegara, 7 (4), pp.458-471. 2015.

C. Darsono, O. and Kusumastuti, T, "Desain Pengelolaan Wilayah Pesisir Pantai Berbasis Masyarakat", Proceedings of the 2015 Seminar Nasional Universitas PGRI Yogyakarta.

D. Purbasari, N. and Asnawi, "Keberhasilan Community Based Tourism di Desa Wisata Kembang Arum, Pentingsari dan Nglanggeran", Jurnal Teknik PWK, 3 (3), pp. 476-485, 2014.

E. Gorris, P, "Deconstructing the Reality of Community-Based Management of Marine Resources in a Small Island Context in Indonesia”, Frontiers in Marine Science, 3 (120), pp. 1-5, 2016. 
F. Blaikie, P, "Is Small Really Beautiful? Community-based Natural Resource Management in Malawi and Botswana", World Development, 34 (11), pp.1942-1957, 2006.

G. Sunaryo, B., Kebijakan Pembangunan Destinasi Pariwisata Konsep dan Aplikasinya di Indonesia, Gava Media, Yogyakarta, Indonesia, 2013.

H. Maliao, R., Pomeroy R. and Turingan, R, "Performance of Community-based Coastal Resource Management (CBRCM) Programs in the Phillipines" Marine Policy, 33, pp.818-825, 2009.

I. Yang, D., “An Impact Analysis of Small-Scale Fisheries Community-Based Fisheries Management (CBFM) in Asia: A Meta-Analysis", PhD Thesis, University of Connecticut, USA, 2017.

J. Slaymaker, T., Christiansen, K. and Hemming, I., Community-based approaches and service delivery: Issues and options in difficult environments and partnerships, Overseas Development Institute, London, UK, 2005.

K. Santoso, S, Buku Latihan SPSS Statistik Parametrik, Elex Media Komputindo, Jakarta, 2000.

L. Kutner, M.H., Nachtsheim, C.J. and Neter, J., Applied Linear Regression Models, 4th ed., New York: McGraw-Hill Companies, Inc, New York, USA, 2004. 